\title{
Bauran Strategi Pemberdayaan Usaha Mikro Dan Kecil (UMK) di Kabupaten Sukabumi
}

\author{
Somadi \\ Program Studi D4 Logistik Bisnis, Politeknik Pos Indonesia \\ Email : somadi@poltekpos.ac.id
}

\begin{abstract}
Abstrak
Usaha mikro dan kecil merupakan salah usaha yang mampu menjadi lokomotif pembangunan ekonomi daerah karena mampu mengurangi tingkat kemiskinan, pengangguran, dan tahan dengan gonjangan krisisi ekonomi. Namun perkembangan usaha mikro dan kecil menghadapi berbagai permasalahan dan tantangan yang harus segera dibenahi oleh semua pihak. Tujuan penelitian ini untuk menghasilkan strategi dan tahapan pemberdayaan usaha mikro dan kecil di Kabupaten Sukabumi. Metode penelitian menggunakan pendekatan kualitatif deskriptif dengan teknik analisis SWOT. Teknik pengumpulan data menggunakan wawancara. Adapun populasi dalam penelitian yaitu seluruh usaha mikro dan kecil di Kabupaten Sukabumi. Banyaknya jumlah sampel dalam penelitian menggunakan snowball sampling dengan metode penarikan sampel menggunakan judgement sampling. Hasil penelitian ini yaitu strategi pemberdayaan usaha mikro dan kecil meliputi optimalisasi sertifikasi produk, ketersediaan bahan baku, dan pembiayaan usaha, manajemen usaha secara professional, pengembangan sarana dan prasarana pendukung, perluasan pangsa pasar, membangun kemitraan usaha, pembaharuan dan pemetaan database, penguatan payung hukum dan kelembagaan, dan iklim usaha yang kondusif. Sedangkan tahapan dalam mengimplementasikan strategi pemberdayaan terdiri dari lima tahapan yaitu tahap identifikasi, tahap pengenalan, tahap pengembangan, tahap percepatan, dan tahap penguatan.
\end{abstract}

Kata Kunci: analisis SWOT, usaha mikro dan kecil, strategi pemberdayaan, tahapan strategi

\begin{abstract}
Micro and small businesses are one of the businesses that are able to become the locomotive of regional economic development because they are able to reduce poverty, unemployment, and withstand economic crisis. However, the development of micro and small businesses faces various problems and challenges that must be addressed by all parties. The purpose of this study is to produce strategies and stages for empowering micro and small businesses in Sukabumi Regency. The research method uses a descriptive qualitative approach with SWOT analysis techniques. Data collection techniques using interviews. The population in this study is all micro and small businesses in Sukabumi Regency. The large number of samples in the study using snowball sampling with the sampling method using judgment sampling. The results of this study are micro and small business empowerment strategies including optimizing product certification, availability of raw materials, and business financing, professional business management, developing supporting infrastructure and facilities, expanding market share, building business partnerships, updating and mapping databases, strengthening the legal umbrella and institutional and conducive business climate. While the stages in implementing the empowerment strategy consist of five stages, namely the identification stage, the introduction stage, the development stage, the acceleration stage, and the reinforcement stage.
\end{abstract}

Keywords: SWOT analysis, micro and small businesses, empowerment strategies, strategy stages

\section{PENDAHULUAN}

Pemberdayaan usaha mikro dan kecil (UMK) merupakan salah satu langkah strategis untuk memperkuat dasar kehidupan bagi perekonomian daerah dan masyarakat Kabupaten Sukabumi. UMKM mempunyai peran penting dalam pembangunan nasional dan penopang perekonomian bangsa, 
karena mampu menyediakan lapangan pekerjaan sehingga dapat menekan angka pengangguran dan kemiskinan, meningkatkan kesejahteraan, dan membangun karakter bangsa (Ikbal et al., 2018). Dengan demikian, bahwa UMK mampu mengurangi penganguran yang terjadi karena UMK mampu menyediakan lapangan pekerjaan sehingga hal tersebut berdampak terhadap pengurangan kesenjangan pendapatan dan tingkat kemiskinan yang ada di Kabupaten Sukabumi.

Berdasarkan data dari BPS Kabupaten Sukabumi tahun 2019, bahwa terjadinya penurunan persentase penduduk miskin yang ada di Kabupaten Sukabumi, dimana persentase penduduk miskin pada tahun 2015 sebesar 8,96 persen, kemudian turun menjadi 8,13 persen pada tahun 2016, dan pada tahun 2017 turun menjadi 8,04 persen. Persentase pengangguran terbuka pada tahun 2017 juga mengalami penurunan dibandingkan tahun sebelumnya menjadi 7,66 persen. Hal ini juga diperkuat oleh data nasional, bahwa adanya peningkatan tenaga kerja pada UMK sebanyak 3.696.225, dimana pada tahun 2016 sebanyak 103.839.015 usaha mikro dan 5.402.073 usaha kecil, sedangkan pada tahun 2017 mengalami peningkatan menjadi 107.232.992 usaha mikro, dan 5.704.321 usaha kecil (Sumber: Kementrian Koperasi dan UKM RI Tahun 2019).

Besarnya kontribusi penyerapan tenaga kerja pada UMK karena dalam perekonomian Kabupaten Sukabumi, UMK merupakan kelompok usaha yang memiliki jumlah paling besar. Saat ini jumlah UMK di Kabupaten Sukabumi pada tahun 2019 sebanyak 25.299 yang tersebar diberbagai kecamatan. Kecamatan yang memiliki jumlah pelaku UMK terbesar berada di Kecamatan Surade sebanyak 2.687 UMK, diikuti Kecamatan Cisaat sebanyak 1.787 UMK, Tegalbuled sebanyak 1.672 UMK, dan Kecamatan Kadudampit sebanyak 1.475 UMK (Sumber: Bappeda Kabupaten Sukabumi Tahun 2019). Pada tingkat nasional, jumlah UMK pada tahun 2017 sebanyak 62.863 .990 pelaku usaha, sedangkan jumlah usaha menengah dan besar masing-masing sebanyak 58.627 pelaku usaha, dan 5.460 pelaku usaha. Jika dibandingkan dengan tahun sebelumnya, jumlah UMK pada tahun 2017 mengalami peningkatan sebanyak 1.269 .365 pelaku usaha.

Selain itu kelompok usaha ini terbukti tahan terhadap berbagai macam goncangan krisis ekonomi, hal ini terlihat meskipun terjadinya krisis yang melandah diberbagai negara, namun keberadaan UMK masih tetap eksis. Namun perkembangan kuantitas UMK yang semakin pesat belum diimbangi oleh kualitas UMK. Hal ini disebabkan karena tidak dapat kita pungkiri bahwa UMK saat ini menghadapi berbagai permasalahan sehingga membuat UMK sulit untuk berkembang, cenderung stagnan, dan ada juga UMK yang mengalami gulung tikar karena tidak mampu menghadapi berbagai permasalahan yang dihadapinya. Selain itu, UMK juga menghadapi berbagai tantangan salah satunya perkembangan teknologi yang semakin maju dan globalisasi ekonomi yang semakin pesat.

Dengan memperhatikan berbagai tantangan tersebut maka diperlukan pemberdayaan UMK yang melibatkan berbagai pihak. Dalam melakukan pemberdayaan UMK harus dilakukan secara terencana baik pada tataran mikro, meso dan makro, serta komitmen penuh dari seluruh stakeholders ditingkat daerah. Hal ini apabila tidak dilakukan komitmen secara bersama-sama maka pemberdayaan UMK akan terhambat untuk berkembang, apalagi maju, dan perencanaan strategi pemberdayaan UMK hanya sebagai hiasan dan tidak mampu diimplementasikan secara optimal.

Dalam rangka melakukan pemberdayaan terhadap UMK guna mengatasi permasalahan dan tantangan yang ada maka diperlukan bauran strategi pemberdayaan UMK. Bauran sendiri menurut Kamus Besar Bahasa Indonesia (KBBI) merupakan sinonim dari campuran, sedangkan strategi adalah rencana yg cermat mengenai kegiatan untuk mencapai sasaran khusus. Dengan demikian, bahwa dalam penelitian ini diharapkan adanya campuran strategi yang mampu untuk memberdayakan para pelaku UMK di Kabupaten Sukabumi. Sehingga strategi yang dihasilkan dari hasil analisis sangat kompleks yang mencakup semua aspek baik internal maupun eksternal. Kemudian, adanya bauran strategi diharapkan nantinya dapat diimplementasikan guna menjawab permasalahan dan tantangan yang ada, serta mampu memberikan peta jalan perencanaan kedepan dan dapat membuahkan hasil yang positif jika disertai dengan langkah-langkah nyata, koordinatif dan berkesinambungan. Penelitian ini juga dapat meningkatkan kualitas perencanaan pembangunan daerah dalam rangka pengembangan UMK di Kabupaten Sukabumi. Dengan demikian, maka tujuan penelitian ini yaitu menghasilkan strategi pemberdayaan usaha mikro dan kecil, dan tahapan implementasi strategi pemberdayaan usaha mikro dan kecil di Kabupaten Sukabumi. 


\section{METODE PENELITIAN}

Objek dalam penelitian ini adalah bauran strategi pemberdayaan UMK, sedangkan subjek dalam penelitian ini yaitu seluruh pelaku UMK (Usaha Mikro dan Kecil) yang berada di Kabupaten Sukabumi dan itu merupakan populasi dalam penelitian ini. Untuk mengambil sampel dalam populasi yang ada menggunakan snowball sampling. Jumlah sampel yang telah dikumpulkan dalam penelitian ini sebanyak 50 sampel pelaku usaha yang bergerak dalam usaha yang berbeda, dan usaha tersebut merupakan usaha terbanyak di Kabupaten Sukabumi. Metode penelitian yang digunakan menggunakan pendekatan kualitatif deskriptif dengan teknik analisis SWOT. Analisis SWOT dapat digunakan untuk memetakan permasalahan, potensi, peluang dan ancaman dalam pengembangan IKM sehingga dapat dirumuskan berbagai strategi peningkatan daya saingnya (Somadi, 2017). Dengan demikian, analisis SWOT bertujuan untuk memetakan faktor-faktor yang menjadi kekuatan atau keunggulan UMK, kelemahan atau permasalahan yang dimiliki oleh UMK, peluang dan ancaman yang dihadapi oleh UMK di Kabupaten Sukabumi, kemudian akan ditentukan strategi pemberdayaan yang tepat berdasarkan pemetaan yang dilakukan. Data yang digunakan berasal dari data primer dengan teknik pengumpulan data menggunakan wawancara kepada para pelaku usaha yang termasuk dalam kategori usaha mikro dan kecil guna memperoleh informasi yang dibutuhkan dalam analisis SWOT. Adapun poin-poin yang ditanyakan ketika wawancara dan dimasukan ke dalam komponen daftar wawancara yakni berkaitan dengan apa yang menjadi keunggulan/kekuatan UMK, kelemahan/permasalahan yang dihadapi oleh UMK, peluang dan ancaman yang dihadapi oleh UMK.Gambar 1 berikut merupakan rancangan kegiatan dalam penelitian ini.

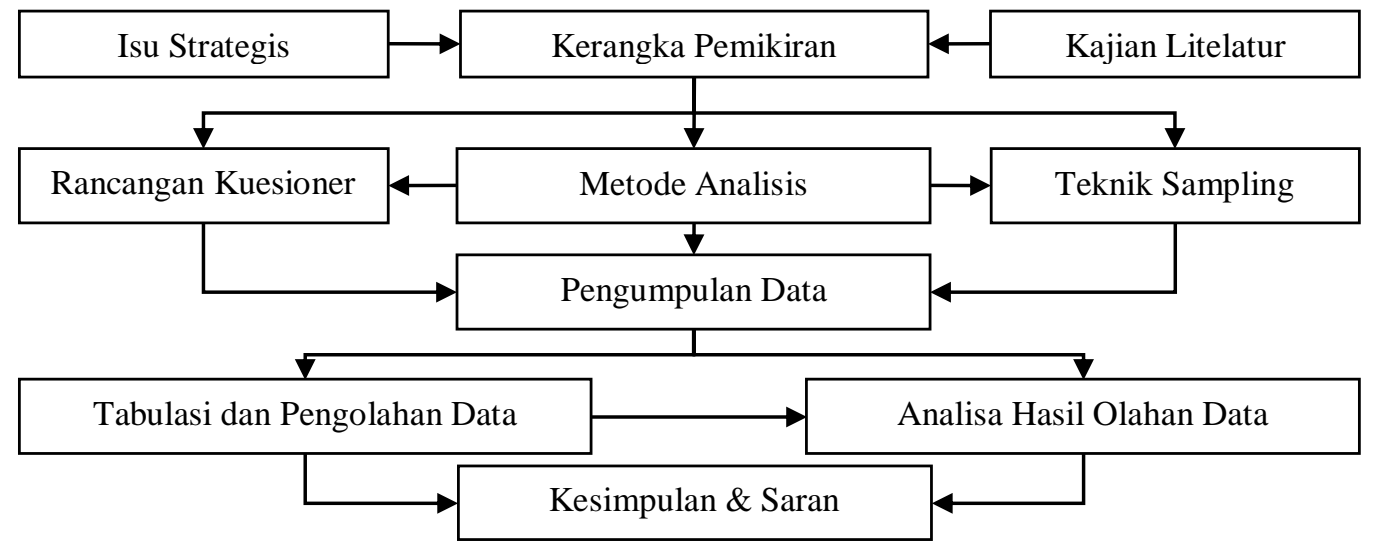

\section{Gambar 1. Rancangan Kegiatan}

\section{HASIL DAN PEMBAHASAN}

Pada Tahun 2019, Kabupaten Sukabumi memiliki jumlah pelaku UMK sebanyak 25.299 UMK yang bergerak dalam berbagai bidang usaha, dan tersebar di berbagai Kecamatan di Kabupaten Sukabumi. Adapun responden dalam penelitian ini yakni perwakilan dari para pelaku UMK yang bergerak dalam berbagai bidang usaha yang tersebar di Kabupaten Sukabumi meliputi usaha gula merah, diikuti anyaman dari rotan dan bambu, alat dapur dari kayu, rotan, dan bambu, furniture dari kayu, penggilingan padi \& penyosohan beras, kerupuk dan sejenisnya, pakaian jadi dari tekstil, pemindangan ikan dan biota perairan lainnya, bata merah, dan bengkel sepeda motor, warung, kue, anyaman dari tanaman selain rotan dan bambu, sembako, genteng, roti, perdagangan, tahu dan tempe, alat pertanian dari logam, dan bergagai jenis makanan ringan. Alasan pemilihan pelaku UMK tersebut sebagai responden dalam penelitian ini karena jumlah pelaku usaha di bidang usaha tersebut merupakan usaha terbanyak yang ada di Kabupaten Sukabumi. Berdasarkan hasil survey yang telah dilakukan, maka dapat dilakukan analisis mengenai keungulan/kekuatan yang dimiliki oleh para pelaku UMK, kelemahan/permasalahan yang dihadapi oleh UMK, peluang dan ancaman dalam perkembangan UMK di Kabupaten Sukabumi. Berikut ini adalah kekuatan, kelemahan, peluang dan ancaman UMK di Kabupaten Sukabumi. 


\subsection{Keunggulan/Kekuatan}

Berikut ini adalah berbagai keunggulan/kekuatan yang dimiliki oleh para pelaku UMK di Kabupaten Sukabumi:

1. Produk memiliki pasar tetap. Produk yang dihasilkan oleh UMK diminati oleh pasar karena UMK telah memiliki pelanggan (pangsa pasar) tetap, sehingga produk yang dihasilkan mampu diserap oleh pasar, dan produk sudah dikenal oleh masyarakat khususnya masyarakat/konsumen lokal. Saat ini pelaku usaha juga sudah mulai berani membuka orderan/pesanan dari konsumen dalam rangka perluasan pasar.

2. Lokasi usaha strategis. Sebagian besar lokasi pelaku UMK berada di tempat yang strategis yakni berada di jalan utama atau jalan besar yang mudah dilalui oleh kendaraan sehingga memudahkan para pemasok dan konsumen untuk mendatangi lokasi usaha UMK.

3. Produk memiliki kualitas baik. Produk yang dihasilkan UMK tergolong memiliki kualitas baik yakni rapi, kuat, tahan lama.

4. Harga jual produk murah. Harga jual produk murah yang ditetapkan oleh para pelaku UMK relatif murah sehingga harga yang ditetapkan terjangkau oleh para konsumen.

5. Produk unik dan khas lokal. Produk yang dihasilkan oleh para pelaku UMK memiliki keunikan dan khas lokal, karena para pelaku UMK menggunakan bahan baku yang berasal dari daerah sekitar dan produk yang dihasilkan merupakan warisan yang sudah turun temurun.

6. Memprioritaskan pelayanan konsumen. Pelaku UMK memprioritaskan pelayanan yang baik kepada para konsumen dengan tujuan agar membuat konsumen merasa puas. Hal ini disebabkan karena apabilan konsumen merasa puas, maka diharapkan konsumen menjadi pelanggan dan mengajak konsumen lain untuk menggunakan produk yang dihasilkan oleh para UMK.

7. Pelaku UMK memiliki keterampilan dalam produksi. Para pelaku UMK memiliki keterampilan ketika memproduksi produk, dan keterampilan sebagian besar diperoleh dari turun temurun seperti contoh usaha pengolahan logam yang merupakan salah satu pengolahan terbaik di Indonesia. Untuk produk makanan, para pelaku UMK melakukan produksi dengan memperhatikan tingkat kebersihan, hal ini agar makanan yang diproduksi sehat. Sebagain besar produk diproduksi secara kontinu tanpa melihat ada pesanan atau tidak ada pesanan dari konsumen. Hal ini bertujuan untuk menjaga ketersediaan produk di tempat penjualan.

8. Kemasan produk menarik dan baik. Produk yang dihasilkan oleh para pelaku UMK sebagian besar telah dilakukan pengemasan untuk memudahkan dalam pendistribusian barang dan menarik konsumen karena kemasan menampilkan berbagai desain yang menarik.

9. Bahan baku berkualitas. Bahan baku yang digunakan oleh para pelaku UMK merupakan bahan baku yang berasal dari lokal yang memiliki kualitas yang sangat baik seperti tanah liat, benang sutra, air bersih, ubi, dan berbagai jenis bahan baku lainnya, sehingga para pelaku UMK sebagian besar menggunakan bahan baku lokal untuk produksinya.

10. Ketersediaan energi untuk produksi memadai. Ketersediaan terkait dengan air bersih, listrik, $\mathrm{BBM}$, gas/kayu untuk mendukung proses produksi cukup berlimpah sehingga pelaku UKM tidak mengalami kesulitan dalam penyediaannya.

11. Penggunaan tenaga kerja lokal. Para pelaku UKM dalam melakukan produksinya menggunakan tenaga kerja dari wilayah sekitar (lokal) dan jumlahnya sangat besar sehingga keberadaa UMK mampu menyerap tenaga kerja lokal dan mengurangi tingkat pengangguran.

Dengan demikian, bahwa yang menjadi keunggulan UMK di Kabupaten Sukabumi meliputi memiliki pasar tetap, lokasi usaha strategis, produk berkualitas, harga murah, produk unik dan khas lokal, prioritas pelayanan konsumen, keterampilan dalam produksi, kemasan menarik dan baik, bahan baku berkualitas, ketersediaan energi memadai, dan penggunaan tenaga kerja lokal. Keunggulan UMK di Sukabumi juga tidak jauh berbeda dengan keunggulan di daerah lain seperti hasil penelitian dari Alyas \& Rakib (2017), bahwa keunggulan usaha Roti di Maros antara lain lokasi usaha yang strategis sehingga mudah dijangkau oleh konsumen, desain tempat yang nyaman sehingga pekerja maupun konsumen menjadi nyaman, roti memiliki aneka rasa sesuai pilihan konsumen, kerharmonisan antar karyawan, harga roti yang ditetapkan terjangkau oleh konsumen, dan adanya penawaran produk lainnya selain roti. Sedangkan berdasarkan hasil penelitian dari Hubeis et al., (2015), bahwa keunggulan UMKM pangan 
yakni UMKM lebih menggunakan bahan baku berbasis lokal dan ketersediaan bahan baku juga selalu tersedia, UMKM telah memiliki merk dan sertifikat halal, makanan yang diproduksi merupakan makanan khas lokal, makanan yang diproduksi disesuaikan dengan selera masyarakat setempat, dan harga produk makanan relatif terjangkau oleh masyarakat.

\subsection{Kelemahan/Permasalahan}

Berikut ini adalah berbagai kelemahan/permasalahan yang dihadapi oleh para pelaku UMK di Kabupaten Sukabumi:

1. Modal usaha terbatas. Modal yang digunakan UMK mayoritas dari modal pribadi dan keluarga karena sebagian besar pelaku UMK belum memanfaatkan fasilitas pembiayaan karena sulitnya UMK untuk mendapatkan kredit atau pendanaan karena ketatnya kriteria pemberian pembiyaan atau kurangnya informasi atas cara mendapatkan pembiayaan dan kurang tersentuh lembaga pembiayaan. Untuk mendapatkan modal, para pelaku UMK masih bergantung pada lembaga keuangan informal, bahkan para pelaku UMK sering terjerat rentenir karena bunga yang sangat tinggi sedangkan keuntungan yang diperoleh masih dibawah tingkat suku bunga pinjaman.

2. Ketersediaan bahan baku terbatas dan harga cenderung meningkat. Sebagian besar ketersediaan bahan baku terbatas, dan cenderung bekurang. Bahan baku juga terkadang sulit didapatkan kecuali bahan baku usaha anyaman, ind. semen, makanan ringan dan basah. Harga bahan baku juga tidak stabil dan cenderung meningkat.

3. Keterbatasan sarana dan prasarana poduksi. Terjadinya keterbatasan sarana dan prasarana poduksi disebabkan karena kebanyakan pelaku UMK memiliki jumlah mesin produksi yang terbatas, sederhana (manual), mesin sudah tua dan sering rusak. Terjadinya masalah ini diakibatkan karena UMK masih kurang dalam memanfaatkan teknologi, padahal tekonologi tersebut mampu memberikan nilai tambah pada produk yang dihasilkan. Hal ini juga dapat disebabkan karena pelaku usaha mengalami keterbatasan informasi teknologi.

4. Jaringan pasar terbatas. UMK mengalami kesulitan dalam membangun jaringan pasar dan pemasaran yang luas, khususnya produk anyaman dan makanan, serta permintaannya tergolong musiman.

5. Kemitraan masih rendah. Sebagian besar UMK belum melakukan kemitraan dengan berbagai pihak sehingga kesulitan untuk mengembangkan pasar, dan mencari bahan baku. Penjualan yang dilakukan UMK masih banyak yang melalui perantara/ tengkulak sehingga harga menjadi murah.

6. Penggunaan media promosi masih rendah. Sebagian besar UMK masih belum menggunakan media promosi untuk media pemasaran, mereka hanya mengandalkan informasi dari mulut ke mulut ataupun teman maupun keluarga.

7. Banyak produk belum tersertifikasi. Sebagian besar pelaku UMK belum memiliki sertifikasi terhadap produknya seperti sertifikasi halal, PIRT, HKI, dan berbagai sertifikasi lainnya.

8. Daya saing produk rendah. Produk yang dihasilkan UMK memiliki daya saing yang rendah sehingga sulit untuk bersaing. Akibatnya UMK mengalami kesulitan dalam pemenuhan spesifikasi produk. UMK masih kesulitan dalam dalam memenuhi spesifikasi produk yang diminta oleh pasar karena produk yang dihasilkan UMK masih banyak yang belum memiliki standar mutu yang sama. Kemudian juga produk UMK lifetime-nya masih pendek.

9. Penjualan sistem kredit. Sebagian UMK menjual produknya ke masyarakat dengan sistem kredit dan pembayaran pembayaran masih telat sehingga menghambat permodalan usaha.

10. Kemasan produk sederhana. Pengemasan produk yang dilakukan sebagian besar UMK masih sederhana karena minimnya informasi mengenai tata cara pembuatan kemasan.

11. Rendahnya inovasi produk. Masih rendahnya inovasi produk yang dilakukan oleh para UMK sehingga membuat nilai tambah produk masih rendah.

12. Tempat produksi menyatuh dengan tempat tinggal dengan lahan yang terbatas. Kondisi tempat produksi yang digunakan dalam proses produksi masih belum tertata dengan baik, tempat produksi yang digunakan masih banyak yang menyatuh dengan tempat tinggal pemilik usaha. Selain itu, masih banyak UMK yang tidak memiliki lahan usaha tetap dan luas lahan usaha yang digunakan oleh UMK kondisinya terbatas. 
13. Pengelolaan usaha belum professional. Pengelolaan kelembagaan UMK masih menerapkan manajemen keluarga yang kurang memperhatikan profesionalisme dan obyektivitas dan dterapkan seadanya sesuai pendidikan dan pengalaman pemilik usaha dan faktor budaya yang membatasi ruang geraknya. Hal ini juga disebabkan karena rendahnya kualitas sumberdaya manusia akibat tingkat pendidikan yang dimiliki masih tergolong rendah sehingga membuat manajemen usaha yang diterapkan masih seadanya dan juga pelaku usaha masih kurang memiliki jiwa wirausaha sehingga menyebabkan pelaku usaha kurang berani untuk mengambil dan menanggung resiko.

Dengan demikian bahwa permasalahan UMK di Kabupaten Sukabumi yaitu modal terbatas, bahan baku terbatas dan harga cenderung meningkat, keterbatasan sarana dan prasarana poduksi, jaringan pasar terbatas, kemitraan masih rendah, penggunaan media promosi masih rendah, banyak produk belum tersertifikasi, daya saing produk rendah, penjualan sistem kredit, kemasan produk sederhana, rendahnya inovasi produk, tempat produksi menyatuh dengan tempat tinggal, pengelolaan usaha belum professional. Permasalahan yang dimiliki oleh UMK di Kabupaten Sukabumi hampir sama dengan yang dimiliki oleh UMK di daerah lain.

Berdasarkan penelitian dari Somadi (2018) tentang usaha penyadapan pohon aren di Desa Wangunsari, bahwa permasalahan yang dihadapi oleh pelaku usaha yaitu bentuk dan kualitas produk belum seragam antar pelaku usaha, pelaku usaha belum melakukan produksi secara kontinyu karena keterbatasan bahan baku, kemasan produk yang tidak menarik karena hanya menggunakan daun kelapa sehingga mudah merosot ketika dibawa dan mudah mencair apabila kenah panas, belum adanya penerapan manajemen usaha karena tingkat pendidikan pelaku usaha sangat rendah yakni mayoritas lulusan SD dengan usia rata-rata sudah tua, saluran penjualan dan promosi yang terbatas karena hanya melalui tengkulak dan promosi dari mulut ke mulut, ketersediaan bahan bakar terbatas karena pelaku usaha mayoritas masih mengunakan kayu, modal usaha yang dimiliki oleh pelaku usaha terbatas karena bersumber modal pribadi, tempat produksi menyatuh dengan tempat tinggal, teknologi yang digunakan yang masih sederhana, dan berbagai kelemahan lainnya. Sementara itu, berdasarkan hasil penelitian dari Prihatin et al., (2017), permasalahan UMKM pada produk kerajinan jahitan dan bordir yaitu pelaku usaha tidak menggunakan promosi dan hanya menunggu pesanan, pelaku usaha tidak memperhatikan tata letak ruang produksi, pelaku usaha jarang melakukan pengembangan keterampilan sehingga keterampilan yang dimiliki tidak berkembang, pelaku usaha tidak menerapkan manajemen dalam menjalankan usaha, pelaku usaha tidak melakukan perhitungan harga pokok produksi (HPP) untuk jasa yang digunakan, dan pelaku usaha tidak pernah menaikan upah pegawai. Dengan demikian, keberhasilan yang dicapai oleh UMKM masih terdapat kelemahan yakni kurangnya akses permodalan sehingga membuat modal menjadi terbatas, kurangnya akses pemasaran, kurangnya kemampuan manajerial sehingga pelaku usaha sulit untuk menjalankan usaha, dan berbagai kelemahan tadi merupakan permasalahan yang selalu dihadapi oleh semua UMKM baik yang baru mulai merintis usaha maupun yang ingin mengembangkan usahanya (Suci, 2017).

\subsection{Peluang}

Berikut ini adalah berbagai peluang dalam pengembangan UMK di Kabupaten Sukabumi:

1. Ketersediaan peraturan, kebijakan dan dokumen perencanaan pengembangan UMK. Tersedianya peraturan dan dokumen perencanaan dari pemerintah baik pusat maupun daerah dalam mendukung pengembangan UMK. Peraturan dan kebijakan tersebut meliputi kebijakan kemudahan impor tujuan ekspor (KITE) bagi UMK, rencana pemberian bunga kredit bagi UMK yang tergolong ringan, kebijakan pemerintahan dan OJK yang kuat mendukung pembiayaan untuk UMK dan mewajibkan penyaluran kredit UMK, dan berbagai fasilitas dan dukungan dari pemerintah lainnya dalam mengembangkan UMK sebagai motor penggerak ekonomi kreatif kedepan.

2. Potensi kemitraan. Saat ini keberpihakan dan komitmen dari berbagai pihak baik itu pemerintah, dunia usaha, masyarakat, dan lembaga lainnya mulai meningkat. Kesadaran dari berbagai pihak tentang pentingnya UMKM dalam kontribusinya terhadap perekonomian juga telah meningkat sehingga peluang terciptanya kemitraan/kerjasama cukup tinggi. 
3. Perubahan struktur perekonomian nasional. Jika dilihat berdasarkan kondisi perekonomian nasional saat ini bahwa struktur perekonomian nasional mengalami perubahan yang sebelumnya berada di sektor pertanian, kini berada di sektor industri dan jasa. Hal tersebut menciptakan peluang bagi UMK terutama yang bergerak di bidang usaha agroindustri, industri kerajinan, industri makanan, dan berbagai jenis industri lainnya sebagai pendukung bahan baku bagi industri besar. Artinya bahwa produk yang dihasilkan oleh UMK dapat diserap oleh usaha besar untuk pendukung proses produksinya.

4. Potensi pasar masih tinggi. Potensi pasar baik pasar dalam negeri dan pasar luar negeri yang terus berkembang dengan seiring berkembangnya jumlah penduduk sehingga potensi permintaan akan barang dan jasa juga akan ikut meningkat kecuali produk anyaman. Kemudian juga, jumlah UMK yang banyak di berbagai sektor dan menyebar di Kabupaten Sukabumi dan Kabupaten Sukabumi merupakan salah satu daerah terluas di pulau Jawa sehingga memungkinkan permintaan terhadap produk yang dihasilkan UMK masih tinggi baik dari para pelaku usaha maupun masyarakat. Kemudian, adanya perjanjian perdagangan internasional yakni MEA, dan kerjasama bidang ekonomi antar negara dapat mempeluas jaringan pasar produk UMK.

5. Bonus angkatan kerja. Saat ini ketersediaan angkatan kerja dalam jumlah besar masih belum mampu untuk dioptimalkan oleh berbagai pihak, padahal angkatan kerja tersebut cukup mampu untuk bekerja pada usaha yang tidak membutuhkan keahlian khusus.

6. Terdapat banyak pilihan lembaga jasa keuangan untuk pembiayaan. Semakin menjamurnya lembaga jasa keuangan menjadi berkah untuk para pelaku UMK sehingga bisa memilih lembaga keuangan yang menawarkan tingkat suku bunga rendah, pelayanan yang sesuai dengan keinginan nasabah, prosedur pinjaman yang mudah, dan lain sebagainya.

7. Berkembangnya teknologi informasi dan komunikasi. Perkembangan teknologi informasi dan komunikasi yang semakin berkembang yang saat ini dikenal dengan industri 4.0 sangat menunjang pengembangan kegiatan bisnis seperti peningkatan produksi karena proses produksi dipadukan dengan teknologi, serta menunjang kemampuan akses pasar secara cepat.

8. Rencana pengembangan ODTW (objek daerah tujuan wisata) baru. Kabupaten Sukabumi direncanakan sebagai daerah baru untuk tujuan wisata (geopark ciletuh) sehingga membuka pangsa pasar untuk para UMK Kabupaten Sukabumi.

9. UMK memiliki potensi yang menjanjian. UMK merupakan salah satu usaha yang menjanjikan bagi penyerapan tenaga kerja melalui penciptaan wirausaha baru karena UMK merupakan usaha yang memiliki daya tampung sangat besar bagi masyarakat yang ingin berwirausaha dalam rangka untuk memperbaiki kondisi ekonominya. UMK juga merupakan usaha yang dengan mudah dapat dijangkau oleh masyarakat, dan UMK memiliki ketahanan yang kuat untuk mengantisipasi dan menyesuaikan terhadap perkembangan pasar karena UMK merupakan pondasi pasar dalam negeri dan merupakan usaha yang paling banyak menggunakan sumberdaya lokal sehingga membuat UMK tidak terpengaruh dengan perubahan kurs mata uang asing.

10. Stabilisasi kondisi politik dan keamanan. Kondisi stabilitas politik dan keamanan di Kabupaten Sukabumi relatif aman dan kondusif sehingga memungkinkan dapat menarik investor untuk berinvestasi di Kabupaten Sukabumi, ditambah saat ini terjadi perubahan dalam hal kebijakan investasi, kebijakan perdagangan dan kebijakan industri menuju industri berbasis pedesaan dan sumber daya alam terutama sektor primer meliputi sektor pertanian, sektor kehutanan, sektor kelautan, sektor pariwisata, dan sektor industri kerajinan rakyat. Sehingga kebijakan tersebut memberikan peluang bagi perkembangan UMK di Kabupaten Sukabumi. Kemudian juga, saat ini di Kabupaten Sukabumi sedang dibangun jalan tol yang menghubungkan berbagai daerah sehingga dipastikan akan menarik banyak investor untuk berinvestasi di Kabupaten Sukabumi karena akan tingginya lalu lintas barang dan manusia.

Dengan demikian, bahwa peluang pengembangan UMK di Kabupaten Sukabumi meliputi ketersediaan peraturan, kebijakan dan perencanaan pengembangan UMK, perubahan struktur ekonomi, potensi pasar, bonus angkatan kerja, berlimpahnya lembaga jasa keuangan, berkembangnya teknologi informasi dan komunikasi, rencana pengembangan ODTW baru, UMK memiliki potensi yang menjanjikan, dan stabilisasi kondisi politik dan keamanan, dan pembangunan jalan tol. Hal senada juga disampaikan oleh hasil 
penelitian Hubeis et al., (2015), bahwa peluang yang dihadapi oleh UMKM di Indonesia yaitu adanya permintaan produk dari masyarakat, terdapat potensi wisata berbasis kuliner, adanya dukungan dari berbagai pihak seperti pemerintah, BUMN, swasta, perguruan tinggi, dan litbang (lembaga penelitian dan pengambangan). Ariani \& Utomo (2017) juga mengungkapkan hal yang tidak jauh berbeda dengan sebelumnya bahwa peluang yang dihadapi oleh para pelaku UMKM di Kota Tarakan yaitu spesialisasi ekspor berupa hasil laut yang tidak dimiliki negara tertangga, gairah konsumsi masyarakat terhadap produk lokal cukup besar, kondisi keamanan yang terjaga dan stabil, adanya program pemerintah tentang pengembangan UMKM, kemudahan dalam proses birokrasi pemerintah, dan ketersediaan infrastruktur pendukung yang memadai(Ariani \& Utomo, 2017).

\subsection{Ancaman}

Berikut ini adalah berbagai ancaman yang dihadapi dalam pengembangan UMK di Kabupaten Sukabumi:

1. Cuaca tidak menentu. Kondisi cuaca yang terjadi di Kabupaten Sukabumi tidak menentu karena cuaca tiba-tiba hujan sehingga membuat usaha UMK yang proses produksinya mengandalkan cuaca menjadi lama. Kemudian, musim hujan yang terjadi tidak menentu mempengaruhi penjualan karena dapat menghambat pendistribusian barang yang rentan rusak terhadap air.

2. Tingkat pesaingan yang ketat. Para pelaku UMK harus menghadapi banyaknya pesaing dalam usaha yang sama kecuali usaha yang bergerak dalam usaha pembuatan kerajinan karena memiliki keunikan dan khas. Kemudian, tingginya tingkat pesaingan di pasar menyebabkan harga penjualan menjadi tidak stabil dan harga yang ditetapkan pesaing relatif murah karena rendahnya biaya produksi dan distribusi. Selain itu juga munculnya pesaing baru baik dalam usaha sejenis maupun subtitusi. Para pesaing juga mampu menerapkan manajemen usaha dan strategi pemasaran yang baik.

3. Kurang koordinasi antar lembaga. Adanya kurang komunikasi antara lembaga membuat pembinaan terhadap UMK belum terencana dan terkoordinasi secara optimal, dan terkadang antar instansi memberikan pembinaan dengan materi yang sama, dan terkadang juga pembinaan dilaksanakan dalam waktu yang berbarengan antar instansi. Sehingga hal tersebut menyebabkan anggaran menjadi boros pembinaan UMK menjadi tidak efektif.

4. Maraknya produk impor di pasar. Produk UMK semakin tersisihkan dengan beredarnya produk impor di pasar baik yang produk yang legal maupun produk yang ilegal. Terkait dengan maraknya produk impor illegal yang terjadi di pasar karena penegakan hukum terhadap produk illegal tersebut dirasa belum dilaksanakan dengan efektif. Kemudian, seiring berkembangnya bisnis ritel skala besar menyebabkan tekanan kepada produk UMK. Dengan demikian pasar dalam negeri semakin dibanjiri produk-produk yang sama atau produk pengganti (produk subtitusi) baik produk yang berasal dari dalam negeri maupun produk yang berasal dari luar negeri akibat pemberlakukan perjanjian perdagangan internasional salah satunya MEA dan CAFTA.

5. Minimnya dukungan dari pihak terkait. Masih minimnya dukungan kepada UMK dari berbagai pihak terkait seperti pemerintah, perguruan tinggi, asosiasi, dan lembaga lainnya.

6. Kondisi infrastruktur kurang memadai. Kondisi infrastruktur jalan dan penerangan di wilayah Kabupaten Sukabumi yang jauh dari perkotaan kondisinya kurang baik, ditambah dengan kultur wilayahnya yang perbukitan dan pegunungan sehingga membuat jalan menurun dan menanjak, berbelok-belok, gelap karena kurang penerangan dan kadang berkabut.

7. Menurunnya daya beli masyarakat. Kondisi daya beli masyarakat saat kini dirasa masih lesu akibat kondisi perekonomian baik ekonomi dalam negeri maupun ekonomi luar negeri yang belum stabil karena adanya wabah virus corona yang terjadi di dunia sehingga hal tersebut memicu terjadinya krisis global salah satunya terjadinya PHK secara besar-besaran karena permintaan pasar terhadap produk menurun, dan terjadinya lockdown di setiap negara sehingga barang sulit untuk masuk ke negara yang menerapkan lockdown tersebut. Dengan adanya PHK tersebut maka membuat masyarakat menjadi tidak bekerja, apalagi kini pemerintah sudah mulai menetapkan PSBB di berbagai daerah dan anjuran untuk dirumah saja sehingga membuat penghasilan semakin menurun. Kemudian juga, konsumen sekarang telah memiliki kemampuan 
untuk memilih produk yang diinginkannya yang diakibatkan penggunaan sistem informasi dan komunikasi yang semakin pesat.

8. Penyaluran pinjaman terbatas. Lembaga jasa keuangan lebih memilih menyalurkan pembiayaan kepada usaha menengah dan besar dibandingkan kepada usaha kecil dan mikro dan usaha yang memiliki agunan jelas, serta beberapa kegiatan usaha UMK belum menjadi sasaran pembiayaan. Kemudian juga, adanya persaingan antar lembaga jasa keuangan dalam menyalurkan kredit sehingga penyaluran terfokus pada debitur lama. Selain itu, adanya keterbatasan alokasi anggaran pemerintah untuk penyediaan pembiayaan dan bantuan untuk UMK.

9. Ketersediaan bahan baku terbatas. Masyarakat yang memproduksi bahan baku yang berasal daerah sekitar beralih profesi ke usaha lain sehingga membuat pasokan menjadi terbatas dan bahan baku menjadi mahal karena bahan baku sulit untuk didapatkan oleh para pelaku UMK. Kemudian juga para pemasok hanya mengirimkan produknya bagi pelaku usaha yang sudah langganan dan mampu membayar secara tunai, jikapun kredit pembayarannya lancar.

10. Ketersediaan tenaga kerja lokal terampil terbatas. Jumlah tenaga kerja lokal yang memiliki keahlian sesuai kebutuhan UMK jumlahnya terbatas.

Dengan demikian bahwa ancaman pengembangan UMK yaitu cuaca tidak menentu, tingkat persaingan yang ketat, kurang koordinasi antar lembaga, maraknya produk impor, minimnya dukungan dari pihak terkait, infrastruktur kurang memadai, menurunnya daya beli masyarakat, penyaluran pinjaman terbatas, ketersediaan bahan baku dan tenaga kerja lokal yang terampil terbatas. Sementara itu berdasarkan hasil penelitian dari Hubeis et al., (2015), ancaman yang dihadapi pelaku UMKM yang memproduksi pangan di Indonesia terdiri dari adanya produk substitusi pangan, jumlah pelaku usaha yang bergelut di bidang pangan berlimpah, maraknya produk makanan impor di pasar, tingginya tingkat persaingan dengan produsen makanan sejenis dengan skala besar, dan kurangnya keberpihakan regulasi pemerintah terhadap UMKM berbasis pangan. Sedangkan ancaman yang dihadapi oleh pelaku UMKM yang berada di Kota Tarakan yang diungkapkan oleh Ariani \& Utomo (2017), meliputi kondisi perekonomian dan inflasi yang tidak mendukung perkembangan usaha, ketidakstabilan ketersediaan pasokan listrik, kurangnya dukungan pemerintah dalam perlindungan usaha, kesulitan perolehan pendanaan dengan bunga lunak dari pemerintah karena prosedur perolehan pendanaan yang rumit. Hal yang sama juga tidak jauh berbeda yang dialami para pelaku UMKM Roti Maros, bahwa faktor yang menjadi ancaman terdiri dari kompetitor baru yang menawarkan produk substitusi, keberadaan pesaing baru dengan produk yang sama, ketidakstabilan harga bahan baku, dan kedekatan lokasi antar pelaku usaha (Alyas \& Rakib, 2017).

\subsection{Strategi Pemberdayaan UMK di Kabupaten Sukabumi}

Berdasarkan hasil analisis terhadap kekuatan dan kelemahan yang dimiliki oleh UMK serta peluang dan ancaman yang dihadapi oleh UMK, maka tahap selanjutnya yakni memetakan kekuatan, kelemahan, peluang dan ancaman yang ada, sehingga dapat mengetahui berbagai strategi yang diperlukan untuk pemberdayaan UMK di Kabupaten Sukabumi. Adapun matriks SWOT terlihat pada gambar 2. 


\begin{tabular}{|c|c|c|}
\hline EFAS & $\begin{array}{l}\text { Kekuatan (Strengths) } \\
\text { 1. Produk memiliki pasar } \\
\text { tetap } \\
\text { 2. Lokasi usaha strategis } \\
\text { 3. Produk memiliki kualitas } \\
\text { baik } \\
\text { 4. Harga jual produk murah } \\
\text { 5. Produk unik \& khas lokal } \\
\text { 6. Memprioritaskan } \\
\text { pelayanan konsumen } \\
\text { 7. Memiliki keterampilan } \\
\text { dalam produksi } \\
\text { 8. Kemasan produk menarik } \\
\text { dan baik } \\
\text { 9. Bahan baku berkualitas } \\
\text { 10. Ketersediaan energi untuk } \\
\text { produksi memadai } \\
\text { 11. Penggunaan tenaga kerja } \\
\text { lokal }\end{array}$ & 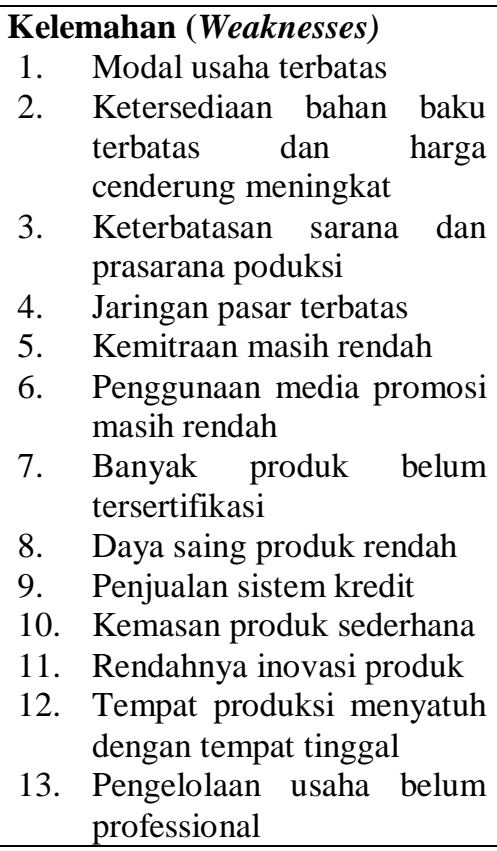 \\
\hline $\begin{array}{l}\text { Peluang (Opportunities) } \\
\text { 1. Ketersediaan peraturan dan dokumen } \\
\text { perencanaan pengembangan UMK } \\
\text { 2. Potensi kemitraan } \\
\text { 3. Perubahan struktur ekonomi nasional } \\
\text { 4. Potensi pasar masih tinggi } \\
\text { 5. Bonus angkatan kerja } \\
\text { 6. Terdapat banyak pilihan lembaga jasa } \\
\text { 7. keuangan untuk pembiayaan } \\
\text { 8. Rerkembangnya TIK } \\
\text { 9. UMK memiliki potensi yang } \\
\text { 10. Stabilisasi kondisi politik dan keamanan } \\
\end{array}$ & $\begin{array}{l}\text { Strategi S-O } \\
* \quad \text { Optimalisasi produksi } \\
\text { produk yang tersertifikasi } \\
* \quad \text { Optimalisasi ketersediaan } \\
\text { bahan baku }\end{array}$ & $\begin{array}{l}\text { Strategi W-O } \\
\quad \text { Penerapan manajemen } \\
\quad \text { usaha secara professional } \\
* \quad \text { Optimalisasi pembiayaan } \\
\text { usaha } \\
* \quad \text { Pengembangan Sarana dan } \\
\text { Prasarana Pendukung } \\
\text { Usaha UMK }\end{array}$ \\
\hline \begin{tabular}{ll}
\multicolumn{3}{l}{ Ancaman (Treaths) } \\
1. Cuaca tidak menentu \\
2. Tingkat pesaingan yang ketat \\
3. Kurang koordinasi antar lembaga \\
4. Maraknya produk impor di pasar \\
5. Minimnya dukungan dari pihak terkait \\
6. Kondisi infrastruktur kurang memadai. \\
7. Menurunnya daya beli masyarakat \\
8. Penyaluran pinjaman terbatas \\
9. Ketersediaan bahan baku terbatas \\
10. Ketersediaan tenaga kerja lokal \\
\\
terampil terbatas \\
\end{tabular} & $\begin{array}{l}\text { Strategi S-T } \\
+\quad \text { Perluasan pangsa pasar } \\
+\quad \text { Membangun kemitraan } \\
\text { usaha }\end{array}$ & $\begin{array}{ll}\text { Strategi W-T } \\
* \quad \text { Melakukan pembaharuan } \\
& \text { dan pemetaan database } \\
& \text { UMK } \\
* & \text { Penguatan Payung Hukum } \\
& \text { dan Kelembagaan } \\
* & \text { Membangun iklim usaha } \\
& \text { yang kondusif }\end{array}$ \\
\hline
\end{tabular}

\section{Gambar 2. Matriks SWOT}

Dengan demikian, berdasarkan matriks SWOT di atas, maka strategi pemberdayaan UMK di Kabupaten Sukabumi adalah sebagai berikut:

1. Strategi S-O (Mengoptimalkan kekuatan untuk memanfaatkan peluang), meliputi:

\$ Optimalisasi produksi produk yang tersertifikasi

* Optimalisasi ketersediaan bahan baku 
2. Strategi W-O (Meminamilisir kelemahan untuk memanfaatkan peluang), meliputi:

* Penerapan manajemen usaha secara professional

* Optimalisasi pembiayaan usaha

* Pengembangan Sarana dan Prasarana Pendukung Usaha UMK

3. Strategi S-T (Mengoptimalkan kekuatan dalam menghadapi ancaman), meliputi:

* Perluasan pangsa pasar

* Membangun kemitraan usaha

4. Strategi W-T (Meniminalisir kelemahan dalam menghadapi ancaman), meliputi:

* Melakukan pembaharuan dan pemetaan database UMK

* Penguatan Payung Hukum dan Kelembagaan

* Membangun iklim usaha yang kondusif

Dengan demikian strategi pemberdayaan UMK di Kabupaten Sukabumi meliputi optimalisasi produksi produk yang tersertifikasi, optimalisasi ketersediaan bahan baku, penerapan manajemen usaha secara professional, optimalisasi pembiayaan usaha, pengembangan sarana dan prasarana pendukung usaha UMK, perluasan pangsa pasar, membangun kemitraan usaha, melakukan pembaharuan dan pemetaan database UMK, penguatan payung hukum dan kelembagaan, dan membangun iklim usaha yang kondusif.

Pada dasarnya, strategi pemberdayaan usaha mikro dan kecil diberbagai daerah ataupun berdasarkan produk usaha tidak jauh berbeda karena yang menjadi keunggulan, permasalahan, ancaman dan peluang yang dihadapi oleh para pelaku usaha di berbagai daerah juga tidak jauh berbeda dan merupakan hal klasik. Perkembangan industri dipengaruhi oleh faktor produksi karena faktor produksi merupakan salah satu faktor untuk menciptakan produk yang meliputi bahan baku utama dan penunjang, tenaga kerja, mesin, dan energi. Apabila industri terus menerus meningkatkan faktor produksinya tanpa diimbangin dengan peningkatan omset usaha, maka industri akan mengalami kebangkrutan karena tingginya biaya produksi sehingga usaha menjadi tidak efisien yang nantinya akan mempengaruhi terhadap keberlanjutan usaha. Namun perlu diperhatikan juga bahwa tidak hanya faktor produksi yang mempengaruhi keberlangsungan usaha, namun faktor eksternal juga berpengaruh terhadap keberlangsungan usaha antara lain pajak, inflasi, transportasi dan logistik (Ishak \& Somadi, 2019). Dengan demikian, maka diperlukan strategi pengembangan usaha untuk mengoptimalkan faktor produksi yang ada guna meningkatkan omset penjualan.

Menurut Ariani \& Utomo (2017), strategi pengembangan UMKM dapat dilakukan dalam dua aspek. Pertama, UMKM diharapkan agar menjaga stabilisasi bahan baku, pemasaran, tenaga kerja, perizinan, perbaikan manajemen usaha, menyediakan sarana dan prasarana yang memadai. Sementara itu, pemerintah dan lembaga terkait agar memberikan pelatihan, sarana dan prasarana serta penyediaan informasi. Sementara itu berdasarkan hasil penelitian dari Anggraeni et al., (2013), strategi pengembangan UMKM Emping Jagung yang berlokasi di Kelurahan Pandanwangi Kota Malang terdiri dari inovasi produk, pengadaan sarana dan prasarana produksi, perluasan jaringan pasar dan peningkatan promosi produk, pengadaan permodalan melalui pemberian akses terhadap sumber permodalan, penguatan pembinaan dan pelatihan. Sedangkan menurut penelitian dari Hubeis et al., (2015), strategi pengembangan UMKM pangan meliputi pembuatan regulasi untuk mengembangkan UMKM pangan, penerapan sistem keamanan dan standar mutu produk, melakukan perbaikan dalam pola pelatihan, pembinaan, pengembangan dan pengawasan agar dapat meningkatkan kreativitas pelaku usaha, penguatan kemitraan dengan pelaku bisnis skala besar dengan lini yang sama, pengembangan teknologi dalam rangka untuk meningkatkan mutu produk, memperkuat kerjasama dalam rangka menjaga pasokan bahan baku, pengembangan kemitraan dengan membangun tempat pemasaran bersama produk UMKM, pembangunan kawasan industri untuk para pelaku UMKM, pembentukan kelompok UMKM yang terdiri dari koperasi, kelompok, sentra, klaster, dan UPT, meningkatkan peran BUMN melalui program CSR perusahaan, penguatan peran pemerintah baik pusat maupun daerah, peningkatan sinergitas antara perguruan tinggi, praktisi, UMKM dan industri pangan, dan mencipatkan UMKM mandiri melalui peningkatan pendampingan oleh tenaga ahli. 


\subsection{Tahapan Implementasi Strategi Pemberdayaan UMK di Kabupaten Sukabumi}

Tahap selanjutnya akan disusun tahapan-tahapan dalam mengimplementasikan strategi pemberdayaan UMK di Kabupaten Sukabumi yang dapat dilakukan kedepan melalui milestone sesuai strategi pemberdayaan UMK yang merupakan hasil analisis dari keunggulan, permasalahan, peluang, dan ancaman dalam perkembangan UMK di Kabupaten Sukabumi yang telah dilakukan sebelumnya. Berdasarkan tahapan implementasi strategi pemberdayaan UMK Kabupaten Sukabumi bahwa terdapat lima tahap. Tahap pertama merupakan tahap identifikasi yang dapat dilaksanakan pada tahun pertama. Pada tahap pertama ini, diharapkan tersedianya database UMK yang update, dan meningkatnya ketersediaan payung hukum dan peran kelembagaan pengembangan UMK. Tahap kedua merupakan tahap pengenalan yang dapat dilaksanakan pada tahun kedua. Tahap pengenalan merupakan tahap untuk memperkenalkan berbagai produk yang dihasilkan ataupun dijual oleh para pelaku UMK di Kabupaten Sukabumi kepada pasar atau calon konsumen. Pada tahap kedua ini, diharapkan meningkatnya pangsa pasar dan omset UMK. Pada tahap selanjutnya merupakan tahap pengembangan yang dapat dilaksanakan pada tahun ketiga. Pada tahap ketiga ini diharapkan dapat meningkatnya jumlah produksi produk yang berkualitas, dan mewujudkan tata kelola usaha yang efektif dan efisien. Pada tahap keempat yaitu tahap percepatan yang dapat dilaksanakan pada tahun keempat dengan harapan dapat meningkatnya permodalan usaha, meningkatnya kualitas dan kuantitas pasokan bahan baku, dan memperkuat jalinan kemitraan usaha. Sementara itu pada tahap kelima merupakan tahap terakhir yakni tahap penguatan yang dapat dilaksanakan pada tahun kelima. Pada tahap kelima ini diharapkan dapat meningkatnya ketersediaan sarana dan prasarana pendukung usaha, dan terciptanya iklim usaha yang kondusif. Gambar 3 berikut adalah tahapan pemberdayaan UMK di Kabupaten Sukabumi.

Sementara itu, berkaitan dengan sasaran yang ada di dalam masing-masing tahapan, maka dapat dirancang sebuah roadmap pemberdayaan usaha mikro dan kecil (UMK) di Kabupaten Sukabumi dengan harapan dapat terwujudnya UMK berbasis pengembangan produk ciri khas lokal yang mandiri dan unggul. Untuk itu dalam mewujudkan sasaran dan tujuan yang diinginkan maka strategi yang perlu dijalankan pada masing-masing tahapan melalui berbagai indikasi program yang perlu dijalankan yang terlihat pada gambar 4 .

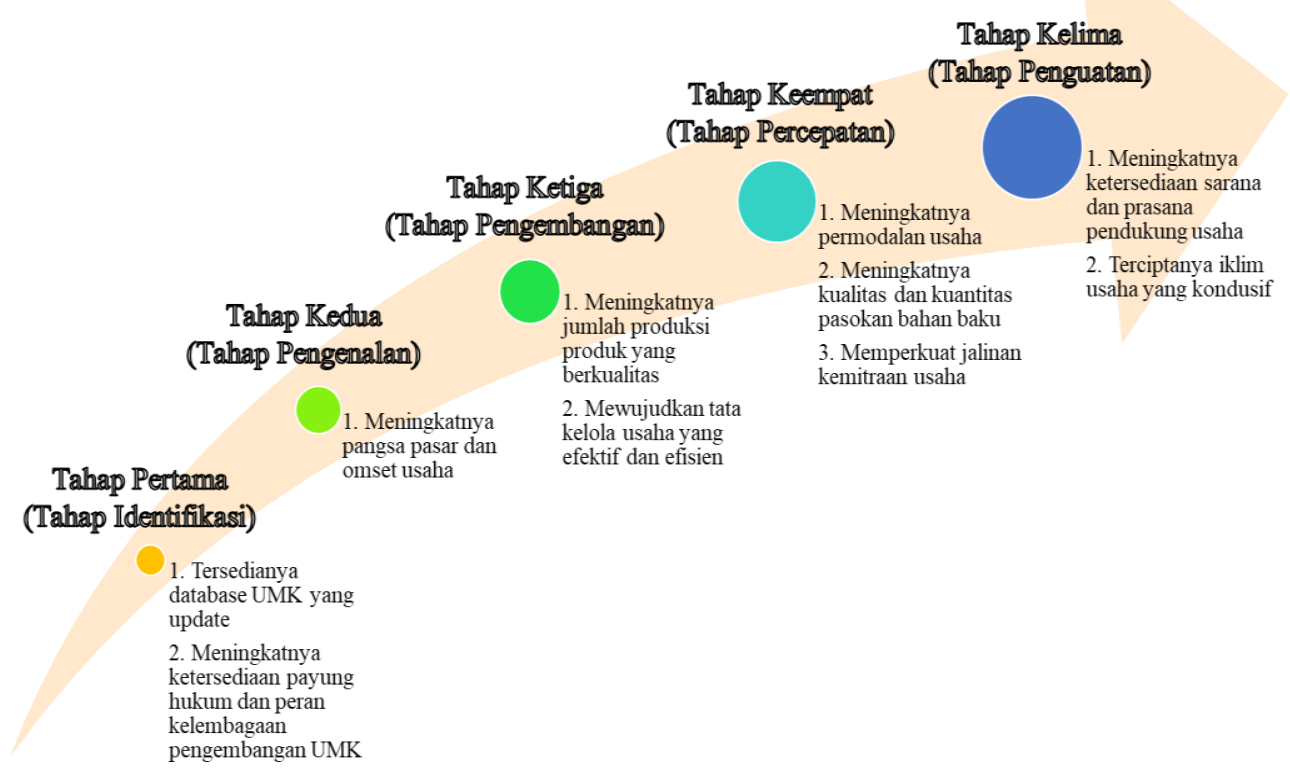

Gambar 3. Tahapan Implementasi Strategi Pemberdayaan UMK Kabupaten Sukabumi

Berdasarkan gambar 4 bahwa indikasi program pada tahap pertama yaitu updating database \& pemetaan UMK, pembentukan Perda pemberdayaan UMK, membangun komitmen penyelenggaraan peraturan pengembangan UMK, dan pembentukan forum koordinasi pemberdayaan UMK. Sedangkan indikasi program pada tahap kedua yaitu melakukan updating variasi media promosi produk, peningkatan promosi produk, penyediaan sarana dan prasana informasi dan promosi produk, dan penguatan branding http://ejurnal.poltekpos.ac.id/index.php/competitive | 45 
produk. Sementara itu indikasi program pada tahap ketiga yaitu peningkatan produktivitas SDM, pencapaian sertifikasi produk, peningkatan produksi produk dan penggunaan teknologi tepat guna, serta peningkatan kemampuan SDM dalam pengelolaan usaha. Untuk indikasi program pada tahap keempat yaitu peningkatan informasi akses pembiayaan usaha, peningkatan kemampuan dalam mengakses pembiayaan dan jumlah pembiayaan yang dapat diserap UMK, penyediaan bahan baku bermutu dan stabilisasi pasokan bahan baku, fasilitasi usaha perdagangan bahan baku, peningkatan peran kelembagaan. Sementara itu indikasi program pada tahap terakhir yaitu kemudahan aksebilitas menuju UMK, stabilisasi pasokan energi, air bersih, dan listrik, penguatan sistem logistik, pengembangan sentra dan klaster industri, pemeliharaan lingkungan, dan stabilisasi kondisi makro ekonomi.

Pada dasarnya strategi yang disusun pada penelitian ini bersifat umum karena bidang usaha yang dijadikan sampel dalam penelitian ini terlalu luas, tidak hanya satu atau beberapa bidang usaha saja, namun lebih dari 10 bidang usaha, sehingga sulit untuk menjelaskan strategi yang khas untuk UMK di Sukabumi. Kemudian juga, penjelasan indikator keberhasilan strategi pun tidak dijelaskan lebih rinci dalam penelitian ini mengingat bahwa penelitian ini baru merumuskan strategi dan tahapan implementasinya, belum mengarah kepada pembuatan rencana strategis sehingga belum terlihat keterkaitan antara strategi dengan indikator capaiannya. 


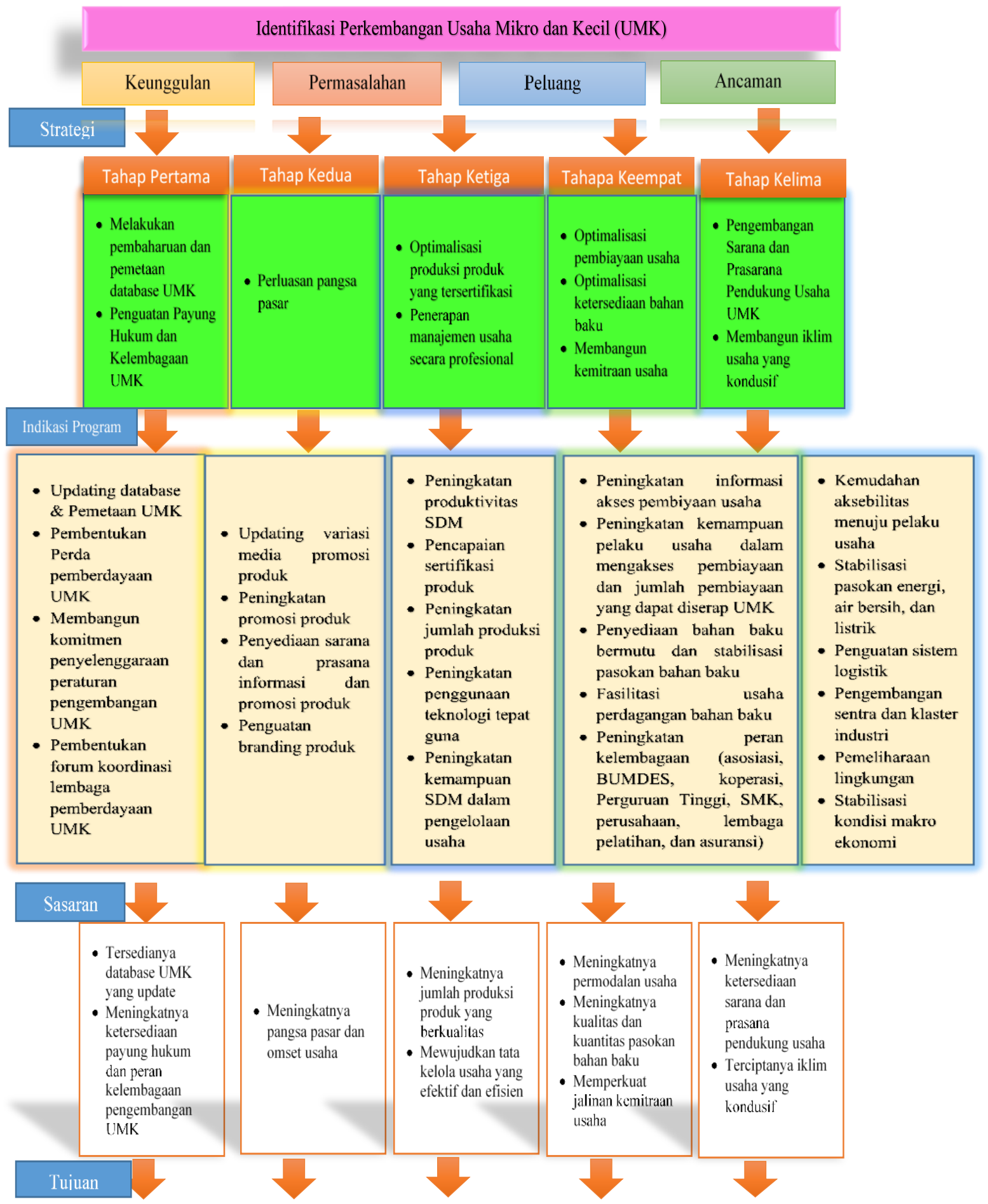

Terwujudnya UMK Berbasis Pengembangan Produk Ciri Khas Lokal Yang Mandiri Dan Unggul

Gambar 4. Rancangan Roadmap Pemberdayaan Usaha Mikro dan Kecil (UMK) di Kab. Sukabumi 


\section{KESIMPULAN DAN SARAN}

Berdasarkan hasil analisa yang telah dilakukan maka dapat disimpulkan bahwa strategi pemberdayaan UMK di Kabupaten Sukabumi meliputi optimalisasi produk yang tersertifikasi dan ketersediaan bahan baku, manajemen usaha secara professional, optimalisasi pembiayaan usaha, pengembangan sarana dan prasarana pendukung usaha UMK, perluasan pangsa pasar, membangun kemitraan usaha, melakukan pembaharuan dan pemetaan database UMK, penguatan payung hukum dan kelembagaan, dan membangun iklim usaha yang kondusif. Sedangkan tahapan-tahapan dalam mengimplementasikan berbagai strategi pemberdayaan UMK terdiri dari lima tahapan yaitu tahap pertama (tahap identifikasi), tahap kedua (tahap pengenalan), tahap ketiga (tahap pengembangan), tahap keempat (tahap percepatan), dan tahap kelima (tahap penguatan). Adapun saran untuk penelitian selanjutnya yaitu melakukan identifikasi berbagai kekuatan, kelemahan, peluang, dan ancaman yang dominan pengaruhnya hingga paling rendah pengaruhnya terhadap perkembangan UMK sehingga strategi yang dioptimalkan nantinya bisa menutupi berbagai faktor yang memiliki pengaruh paling besar terhadap perkembangan UMK di Kabupaten Sukabumi.

\section{REFERENSI}

Ikbal, M., Mustafa, S. W., \& Bustami, L. (2018). Peran Usaha Mikro, Kecil Dan Menengah Dalam Mengurangi Pengangguran Di Kota Palopo. Jurnal Ekonomi Pembangunan, 4(1), 35-46.

Badan Pusat Statistik Kabupaten Sukabumi. (2019). Kabupaten Sukabumi Dalam Angka. Kabupaten Sukabumi: BPS Kabupaten Sukabumi.

Badan Perencanaan Pembangunan Daerah Kabupaten Sukabumi. (2019). Data UMK Kabupaten Sukabumi Tahun 2019. Kabupaten Sukabumi: Bappeda Kabupaten Sukabumi.

Kementrian Koperasi dan UKM RI. (2019). Perkembangan UMKM Nasional. Jakarta: Kementrian Koperasi dan UKM RI.

Somadi, S. (2017). Strategi Peningkatan Daya Saing Industri Kecil dan Menengah (IKM) Gula Aren di Kabupaten Bandung Barat. Magister Teknik Industri Universitas Pasundan.

Alyas, A., \& Rakib, M. (2017). Strategi Pengembangan Usaha Mikro, Kecil, Dan Menengah Dalam Penguatan Ekonomi Kerakyatan (Studi Kasus Pada Usaha Roti Maros di Kabupaten Maros). Sosiohumaniora, 19(2), 114-120.

Hubeis, M., Purwanto, B., Dewi, F. R., Widyastuti, H., \& Febtyanisa, M. (2015). Strategi Pengembangan UMKM Pangan Yang Berdaya Saing Di Indonesia. Prosiding Seminar HasilHasil PPM IPB, I(1), 126-143.

Somadi, S. (2018). Penerapan Analisis Swot Dalam Upaya Pengembangan Usaha Penyadapan Pohon Aren Di Desa Wangunsari. Competitive, 13(1), 8-20.

Prihatin, L., Lubis, A. N., \& Sitti, R. A. S. (2017). Pengembangan Usaha Mikro Kecil Dan Menengah (UMKM) Kerajinan Menjahit Dan Bordir Di Kecamatan Medan Area Kota Medan. Abdimas Talenta, 2(1), 41-47.

Suci, Y. R. (2017). Perkembangan UMKM (Usaha Mikro Kecil Menengah) di Indonesia. Jurnal Ilmiah Cano Ekonomos, 6(1), 51-58.

Ariani, A., \& Utomo, M. N. (2017). Kajian Strategi Pengembangan Usaha Mikro Kecil dan Menengah (UMKM) di Kota Tarakan. Jurnal Organisasi Dan Manajemen, 13(2), 99-118.

Ishak, R. F., \& Somadi, S. (2019). Analisis Efisiensi Industri Kreatif Unggulan Kota Bandung Dengan Pendekatan Data Envelopment Analysis. Competitive, 14(1), 1-13.

Anggraeni, F. D., Hadjanto, I., \& Hayat, A. (2013). Pengembangan Usaha Mikro, Kecil Dan Menengah (UMKM) Melalui Fasilitasi Pihak Eksternal Dan Potensi Internal (Studi Kasus Pada Kelompok Usaha "Emping Jagung" Di Kelurahan Pandanwangi Kecamatan Blimbing Kota Malang). Jurnal Administrasi Publik Mahasiswa Universitas Brawijaya, 1(6), 1286-1295. 